\title{
The Pan American Congress of Ophthalmology, 1940
}

It is a matter for regret that, under existing conditions with regard to paper shortage, we are not able to give more than a brief abstract of the material which has been sent to us by Dr. Moacyr E. Alvaro, of Sao Paulo, Brazil.

The Congress was sponsored by the American Academy of Ophthalmology. The chairman was Dr. Harry S. Gradle and the organising secretaries, Dr. Conrad Berens of New York and Dr. Moacyr Alvaro. Papers were read in English, Spanish and Portuguese. The papers were well discussed and the Congress appears to have been a great success. The next meeting has been arranged, circumstances permitting, to be held in Monte Video in 1943.

The following is a list of the papers which were read.

MANUEL URIBE TRONCOSO (New York).-On the value of gonioscopy in the prognosis and treatment of glaucoma.

Albert C. SNELl and ScotT Sterling (Rochester, New York).-A mathematical interpretation of field acuity.

William L. Benedict (Rochester, Minn.).-Orbital hyperostosis.

J. M. de BARros (São Paulo).-Ocular leprosy.

A. Solares (Sucre, Bolivia).-Kerato-conjunctival lesions prevalent in the high altitudes of Bolivia.

DERRICK T. VAIL (Cincinnati, Ohịo).-Hyphaema after cataract operation.

S. HANFORD MCKEE (Montreal),-Observations on the fundus oculi in diabetes mellitus.

A. VASQUEZ-BARRIERE (Montevideo).-Hypertonic rigidity of convergence, or False paralysis of divergence.

Tomas YANES (Habana, Cuba).-Dacryocysto rhinostomy.

ARTHUR A. Bedell (Albany, New York).-Unusual lesions illustrated with coloured fundus photographs.

Manuel MarqueZ (Madrid). - The best and most exact method of diagnosing small astigmatic errors by means of bicylindrical combinations.

C. DE ANDRADE (Bahia, Brazil).--Interstitial and ulcerative keratitis in Leishmaniasis

JoHN O. MCREYNOLDS (Dallas, Texas).-Complications of cataract removal and measures that may be employed for their relief.

H. FERRER (Cuba).- - Intra capsular extraction of cataract with a new vent.

Rodman IRvine (Los Angeles).-Further observations on the nature, aetiology and significance of exfoliation of the lens capsule.

A. Quevedo (Guatemala).-Ocular filiarosis, ocular symptoms of onchocerciasis.

-Alan C'. Woons and J. S. Guyton (Baltimore).-Advances in the use of sulphanilamide compounds in ophthalmology. 
C. Charlin (Santiago, Chilie).-Toxic syndrome of ocular tuberculosis. SANFORD R. GIFFORD (Chicago).-Further report on tendon transplantation for abducens paralysis.

J. P. Gomes (Sao Paulo).- - Tumours of the optic nerve.

DANIEL-B. KIRBY (New York). - Congenital bilateral colobomata of the upper and lower eyelids, surgical correction by sliding pedicle flap.

J. L. Pavia (Buenos Aires).-Use of sodium light in fundus examination.

G. G. JAYme (Annapolis, Goyaz, Brazil).-Cephalic tetanus following ocular injury.

C. DE ANDRADE (Brazil).-The conjunctiva as an entrance of infection in Chages' disease (American Typanosomiasis).

\section{Lot 117: A Collection of Spectacles}

"If there is any exhibition in all Vanity Fair which satire and sentiment can visit arm in arm together; where you light on the strangest contrasts laughable and tearful : where you may be gentle and pathetic, or savage and cynical with perfect propriety: it is at one of those public assemblies, a crowd of which are advertised every day in the last page of the Times newspaper, and over which the late Mr. George Robins used to preside with so much dignity. There are very few London peoplé, as I fancy, who have not attended at these meetings, and all with a taste for moralising must have thought, with a sensation and interest not a little startling and queer, of the day when their turn shall come too, and Mr. Hammerdown will sell by order of Diogenes's assignees, or will be instructed by the executors to ofter to public competition, the library, furniture, plate, wardrobe and choice cellar of wines of Epicurus deceased."

These opening words of the seventeenth chapter of Vanity Fair always occur to the writer's mind, when, as occasionally happens, he visits a country auction. We do not mean to say that we attend the sales of fat stock, farm implements, etc. But not long ago, happening to see in a catalogue a lot of miscellaneous spectacles, we thought we would have a look at them. The strange contrast in this particular case was that mixed up with a very ordinary lot of fairly modern steel-rimmed spectacles there were numerous examples of the cut-throat type of razor. Any idea that we might perhaps acquire an old pair of Queen Anne silver-rimmed spectacles, shall we say, or even a gross of green spectacles "with silver rims and shagreen cases" was doomed to disappointment. The only item of interest in the whole lot was an old-fashioned spectacle case inlaid with mother of pearl of the type our grandmothers used to put their spectacles in. This particular lot was evidently an accumulation of "junk" acquired over years of dealing in the second-hand antique way and Diogenes, in this instance, had not died but was giving up business. 